\title{
Religious Heterogamy and the Intergenerational Transmission of Religion in China
}

Brian L. McPhail, Purdue University, West Lafayette, Indiana, USA

Fenggang Yang, Purdue University, West Lafayette, Indiana, USA

\begin{abstract}
In Western societies, religious heterogamy and its effects on religious socialization outcomes have been interpreted through the lens of secularization. How about China, where religion has been resurging in recent decades? Using data from the 2007 Spiritual Life Survey of Chinese Residents, this study shows that despite China's atheist education system and strict religion policies, having at least one religiously affiliated parent is associated with increased religiosity compared to having two nonreligious parents. Whereas religious heterogamy in the West has a secularizing effect on the next generation, religious heterogamy in secular nations such as China has a religionizing effect and contributes to religion's rise.
\end{abstract}

Keywords: Religious socialization; heterogamy; China; secularization

"This is the pre-peer reviewed version of the following article: McPhail, Brian L., and Fenggang Yang. 2020. "Religious Heterogamy and the Intergenerational Transmission of Religion in China." Journal for the Scientific Study of Religion 59(3):439-54., which has been published in final form at 10.1111/jssr.12667. This article may be used for noncommercial purposes in accordance with Wiley Terms and Conditions for Use of SelfArchived Versions." 


\section{Introduction}

Research has long established that religious heterogamy, in which spouses do not share the same religious affiliation, is less effective at socializing children into religion than religious homogamy (Putney and Middleton 1961; Havens 1964; Hoge and Petrillo 1978; Nelsen 1990; Roof 1999; Pew Research Center 2016). Because these studies were conducted in Western societies, religious heterogamy has been understood as another indicator of the long-term trend of religious decline, i.e., secularization (Petersen 1986; Kalmijn 1991; Rosenfeld 2008; Bruce 1999, 2011; Voas and Storm 2012). Increased religious diversity has led to increased religious heterogamy, which in turn has led to religious decline across generations (Voas and Chaves 2016). Although this interpretation fits the trend in many Western contexts, we propose that religious heterogamy could also be an indicator of and contributor to religious vitality in a different social context. In China, for instance, religion was nearly eradicated through a systematic secularization program engineered by the Communist party-state. In recent decades, however, religion has revived amid economic market transition and globalization (Yang 2005; Chau 2010; Yang 2011). In this context of religious resurgence, religious heterogamy can be positively associated with religious vitality, particularly if religiously heterogamous parents are effective at socializing their children into religion.

This article is an empirical study to determine the impact of religious heterogamy on the religiosity of adult children in China. We emphasize the importance of contextual factors, namely the religious demographics of a society, in interpreting the effects of religious heterogamy on the intergenerational transmission of religion. Using data from the 
2007 Spiritual Life Survey of Chinese Residents (SLSC), we examine the effects of having only one religious parent on a variety of religious outcomes in mainland China. We find that individuals with one religiously affiliated parent are significantly more likely to be religious than individuals with two unaffiliated parents. Despite the strict religious policies of the Chinese party-state and the promotion of atheism among its citizenry, having at least one religiously affiliated parent increases the likelihood of having a religious affiliation, believing in God/gods, participating in religious activities, and reporting greater religious salience. Our findings suggest that not only do religiously heterogamous parents play a critical role in shaping the religious lives of their children, they also contribute to the growth of religion among China's younger generations. Whereas religious heterogamy in the West has been understood as an indicator of religion's generational decline, religious heterogamy in secular nations such as China is actually an indicator of religion's rise. This has important theoretical implication for the paradigmatic debate regarding religious decline and religious vitality (Warner 1993; Stark and Finke 2000; Berger, Davie, and Fokas 2008; Voas and Chaves 2016).

\section{The Intergenerational Transmission of Religion}

The most important and enduring social influence on the religious lives of both adolescents and adults is the religiosity of their parents (Myers 1996; Sherkat 1998; Regnerus, Smith, and Smith 2004; Park and Ecklund 2007; Smith and Denton 2009; Denton and Culver 2015). Although other social factors including spousal religiosity, strong network ties, aging and life course events (i.e., marriage and parenthood), and recent 
religious experiences also play key roles in shaping individual religiosity (Roof and Hoge 1980; Willits and Crider 1989; Hoge 1994; Chaves 1991; Wilson and Sherkat 1994; Stolzenberg, Blair-Loy, and Waite 1995), the religiosity of one's parents is the strongest predictor overall.

Several theoretical explanations propose how religious beliefs, values, and behaviors are transmitted, reinforced, and reproduced across generations. The first explanation derives from social learning theory (Bandura and Walters 1977) and suggests that children observe and imitate the religious behavior of their parents. Therefore, more religious parents who strongly emphasize religion in the home produce religious children (Hunsberger and Brown 1984; Willits and Crider 1989; Myers 1996; Bengtson et al. 2009; Smith and Denton 2009). The second explanation postulates that parents "channel" children into religious institutions, environments, and social networks where their religious beliefs and values are reinforced (Himmelfarb 1979; 1980; Cornwall 1989; Erickson 1992; Martin, White, and Perlman 2003; Regnerus, Smith, and Smith 2004). The third explanation claims that greater affection and solidarity in the family increases the likelihood that children adopt the religion of their parents (Bengtson, Biblarz, and Roberts 2002). Both the social bonds between parents and children (Hoge and Petrillo 1978; Nelsen 1980; Clark and Worthington 1990; Myers 1996; Sherkat 1998; Bengtson, Biblarz, and Roberts 2002; Smith and Denton 2009; Denton and Culver 2015) and between the parents themselves (i.e., marital status and marriage quality) (Myers 1996; Lawton and Bures 2001; Regnerus, Smith, and Smith 2004; Zhai et al. 2007) are predictors of religiosity in adult children. 
Parental religious heterogamy, however, complicates the process of the religious socialization of children. Early research consistently found that individuals with parents who do not share the same religion are less religious overall than individuals with samefaith parents (Anders 1955; S. Putney and Middleton 1961; Havens 1964; Hoge and Petrillo 1978). More recent studies have confirmed these earlier findings (Nelsen 1990; Roof 1999; Pew Research Center 2015) and have shown that interreligious couples are less likely to practice religion with their children (Roof 1999; Petts and Knoester 2007), less likely to "channel" their children into religious environments (Pew Research Center 2016), and more likely to experience interpersonal conflict or marital instability that disrupts the affective bonds of the family (Hoge and Petrillo 1978; Myers 1996; Call and Heaton 1997; Curtis and Ellison 2002; Petts and Knoester 2007; Wright, Rosato, and O'Reilly 2017).

Although these U.S.-based studies have consistently shown negative associations between parental religious heterogamy and the religiosity of their offspring, they have primarily been interested in investigating the secularizing effects of religious heterogamy. In doing so, they compare the religiosity of individuals with parents who did not have the same religion to the religiosity of individuals with parents who did have the same religion. Researchers have not explicitly examined religious inheritance when only one parent is religious but the other is nonreligious, nor compared the religious socialization outcomes of religiously heterogamous parents with those of two nonreligious parents. This lack of research is probably due to the fact that religious "nones" in the U.S. are still too few and too new to quantitatively assess its impact on the religious socialization of children. Furthermore, the proportion of parents in the U.S. population who are religiously 
heterogamous or both nonreligious remains low. In contrast, China offers the opportunity for making such comparisons as the majority of marriages are between two religiously unaffiliated partners but about 14 percent are between one religiously affiliated partner and one religiously unaffiliated partner.

\section{Religious Heterogamy and Its Impact on Religious Socialization in China}

The question of whether having only one religious parent is associated with higher levels of religiosity than having two nonreligious parents is particularly intriguing when asked within the socio-political context of China, a society where there are many social influences that discourage believing and practicing religion and where religious believers are in the minority. The ruling Chinese Communist Party has continued to uphold an atheist ideology for the country by enforcing atheist education from elementary school to graduate school, by promoting atheist propaganda through mass media and the press, and by fortifying their organizations, the Chinese Communist Party, the Chinese Communist Youth League, and the Young Pioneers for school-age children (Yang 2018). In this strongly atheist social context, if individuals who have a single religious parent are more likely to become religious, it not only confirms the significance of parental influence on the religious outcomes of their children, but also draws attention to the role of the family in the growth of religion in contemporary China.

However, existing studies on the interaction between the national context and family background in the transmission of religion across generations predict opposite outcomes. First, in Communist-ruled countries where there are anti-religious policies, the 
significance of religious socialization on personal religiosity decreases, primarily by raising the personal costs of religious socialization and by suppressing religion in general (Müller, De Graaf, and Schmidt 2014). The Chinese Communist party-state has maintained one of the most restrictive religious policies in the world. In fact, it has the highest score of any nation on the Government Restriction Index (GRI), a measure of how strict government's policies are towards religious belief and practice (Pew Research Center 2018). The official doctrine of the Chinese Communist Party (CCP) is atheism, which is taught in schools to Chinese students as core to the ideology of the Chinese socialist system (MEPRC 2001; Renminwang 2006; Yang 2011; Xie, Tong, and Yang 2017), and the mass media are considered channels for atheist propaganda (SMRT 2003; Zhongxuanfa 2004). The religious education of children under 18 years old is usually prohibited, ${ }^{1}$ which combined with other anti-religious policies, may discourage religious parents from actively teaching religion to their children. China's strict religious environment suggests that effects of religious socialization on personal religiosity will be diminished, particularly if only one parent is religious.

${ }^{1}$ This restrictive policy may not be enforced in all places all the time. There are occasional exceptions, such as recognizing a child as a living Buddha in the Tibetan Buddhist tradition. In the reform era since the late 1970s, there have been periods of lapsed enforcement. However, when militant atheism prevails, there are renewed pronouncements and restrictions, such as Zhongxuanfa (2004). 
Second, parental religiosity has diminished effects on personal religiosity in societies with high-levels of income inequality (Müller, De Graaf, and Schmidt 2014). Income inequality is a strong driver of religiosity (Norris and Inglehart 2011; Solt, Habel, and Grant 2011), so in societies with higher levels of income inequality, individuals with less religious parents are nearly as religious as individuals with highly religious parents. The income inequality in China today is among the highest levels in the world with a Gini coefficient above 0.5 (Xie and Zhou 2014). This suggests that the influence of one's family religious background might matter less in China.

On the other hand, the effect of parental religious socialization is greater in secular nations than in more religious nations (Kelley and De Graaf 1997; Voas and Storm 2012). Being born into a religious nation that has a widespread religious culture and a high proportion of religious people decreases the overall influence of parents on personal religiosity, whereas being born into a secular nation where there are fewer religious people increases the religious influence of parents (Kelley and De Graaf 1997; Voas and Storm 2012). A high percentage of China's population is nonreligious, as only about 20 percent of the population self-identify with a particular religion. This suggests that the influence of one's parental religious background might matter more in China than in more religious nations.

Based on the research described above, we have developed competing hypotheses about the effect of having one religious parent on an individual's religiosity in China. Because China has high levels of income inequality and strong anti-religious policies, the 
impact of having one religious parent on an individual's personal religiosity may be diminished:

H1: Having one religiously affiliated parent will NOT result in higher levels of religiosity compared to having two religiously unaffiliated parents.

However, because China is a predominately secular society where there are more nonreligious people than religious people, religious socialization by the parents should have a greater effect on personal religiosity:

H2: Having one religiously affiliated parent will result in higher levels of religiosity compared to having two religiously unaffiliated parents.

\section{Methods}

\section{Data}

To test these hypotheses, we used data from the 2007 Spiritual Life Study of Chinese Residents (SLSC), a national multi-stage probability sample $(N=7,021)$ of citizens (above 16 years of age) in China. Respondents were selected from 56 cities, towns, and villages, which represent all of China's provinces, municipalities, and autonomous regions with the exceptions of Xinjiang and Tibet. Households were sampled within neighborhoods, and neighborhoods were sampled within each locale. One member of each household was randomly selected for a face-to-face interview using a KISH grid procedure. The response rate (AAPOR RRI) of the final sample is $28.1 \%$, and the final data set is weighted according to demographic information in the 2006 Statistical Yearbook of China. 


\section{Dependent Variables}

The phenomenon of religion is multi-dimensional, and no single indicator can represent the complexity of religious life (King and Hunt 1972; Himmelfarb 1975; Levin, Taylor, and Chatters 1995; L. Pearce and Denton 2011; Pearce, Hayward, and Pearlman 2017; Chao and Yang 2018). Fortunately, the SLSC includes a large set of measures for religiosity in the Chinese socio-cultural context. To test the hypotheses about the effect of religious heterogamy on the intergenerational transmission of religion in China, we used measures of religious affiliation, beliefs, behavior, and salience as the dependent variables.

The first dependent variable is a dichotomous measure of whether respondents have a religious affiliation. The SLSC asked, "Regardless of whether you have been to churches or temples, do you believe in any of the following?" We recoded responses of "Buddhism," "Daoism," "Confucianism," "Protestantism," "Catholicism," and "Islam” as 1, and "I don't believe in anything/I don't have any religious belief" as 0 . Having a belief in God/gods is measured by the SLSC question "Which one of the following statements is closest to your view of God/gods?" We recoded responses of "There is only one true God" or "There are many gods" as 1 in a new dichotomous variable.

The SLSC also asks respondents whether they have participated in a variety of religious activities in the past year including attending services in churches, mosques, or temples and prayer, worship, and incense burning in temples. Respondents who answered affirmatively for any of these questions were asked a single follow-up question about their frequency of participation in religious activities: "In general, did you participate in these activities regularly or only occasionally?" The coded responses ranged from 2 = "only 
occasionally" to $5=$ "daily." No participation in religious activities in the past year was coded as 1 . Given the prevalence of ancestor worship and the discrepancy of whether it is a religious activity, we coded respondents who only "venerated ancestral spirits by their graves" during the past year as 1. Finally, respondents were asked about the importance of religion in their lives using a 4-point scale. We reverse coded the responses to obtain a religious salience measure in which 1 = "Not at all important," 2 = "Somewhat Unimportant," 3 = "Somewhat Important," and 4 = "Very Important."

\section{Parents' Religious Heterogamy}

The focal independent variable is religious heterogamy in the respondents' parents as measured by their religious affiliations. The SLSC asked respondents to recall the religious affiliations of their fathers and mothers when the respondents were 15 years old. Response options included "Buddhism," "Daoism," "Confucianism," "Protestantism," "Catholicism," "Islam," and "No religious belief." Using these responses, we constructed a new nominal variable with four categories: parents who shared the same religious affiliation, parents with two different religious affiliations, parents in which only one was religiously affiliated, and parents who were both religiously unaffiliated. Two of these categories, parents with two different affiliations and parents in which only one was religiously affiliated, represent religious heterogamy.

In the SLSC dataset, 9 percent of respondents had parents with the same religious affiliation $(n=541), 6$ percent of respondents had only one affiliated parent $(n=374)$, and 
85 percent had two unaffiliated parents $(n=5,359) .{ }^{2}$ Only eight respondents $(0.13$ percent had parents with two different religious affiliations. ${ }^{3}$ Because there are too few respondents of this type to obtain reliable estimates, we excluded them from the models. Therefore, we only compared those people with religiously heterogamous parents with those whose parents had the same religion or both had no religion.

\section{Control Variables}

In these analyses, we included as additional covariates socio-demographic characteristics known to be associated with the religious lives of individuals and families (Williams and Lawler 2002; Gunnoe and Moore 2002; Sullins 2006; Mayrl and Oeur 2009; Schwadel, McCarthy, and Nelsen 2009). These include age (ranges from 16-75), gender (female $=1)$, annual household income level (measured in 7 categories), marital status

${ }^{2}$ In the SLSC survey, religious heterogamy is reported more frequently for respondents and their spouses (14 percent) than for respondents' parents ( 6 percent). Auxiliary analyses of these data suggest that the SLSC undercounts the number of respondents with only one religious parent, likely because respondents either misremembered or were not aware of the religious affiliation of their parents at age 15 .

${ }^{3}$ Of the eight respondents with parents who had two different religious affiliations, six were characterized by "across-religion" religious heterogamy in which one parent was affiliated with a Chinese traditional religion (Buddhism, Daoism, or Confucianism) and one parent was affiliated with a non-traditional Chinese religion (Protestantism, Catholicism, or Islam). The other two were characterized by "inter-Chinese" religious heterogamy in which each parent was affiliated with a different Chinese traditional religion (Buddhism, Daoism, or Confucianism). 
$($ married $=1)$, education level (measured in categories, $1=$ less than elementary school, $2=$ elementary school, $3=$ junior high school, $4=$ high school or technical high school, $5=$ college, 6 = bachelor's degree, 7 = master's degree or higher), urban/rural residence (urban $=1)$, and political affiliation (Chinese Communist Party $(\mathrm{CCP})$ member $=1)$.

\section{Analytic Strategy}

To examine the associations between parental religious heterogamy and respondent religiosity, we used logistic regression models because our measures of religiosity are categorical variables (Long and Freese 2006). First, using binary logistic regression for models with dichotomous dependent variables, we estimated the effect of having one religious parent on the likelihood of respondents having a religious affiliation and believing in God/gods. Next, for the dependent variables with clear ordered categories but inconsistent intervals between them, we used ordered logistic regression to estimate models examining the effect of having one religious parent on religious salience and frequencies of service attendance/visits to religious sites during the past year.

All models included the full set of covariates. In addition to the 8 cases in which the respondents' parents had two different religious affiliations, we excluded observations with missing data on any of the dependent or independent variables using list-wise deletion, producing a final analysis sample size of $n=6,476$. We conducted these analyses using STATA (version 15 ) with $\alpha=.05$ to identify statistically significant results. 


\section{Results}

[Table 1 ABOUT HERE]

Table 1 shows the descriptive statistics of all variables in the weighted analysis sample. About 21.4 percent of the entire sample has a religious affiliation. For respondents with two religiously affiliated parents, 70.4 percent have a religious affiliation; for respondents with only one affiliated parent, 45 percent have a religious affiliation; and for respondents with no religiously affiliated parent, only 14.2 percent have a religious affiliation. Overall, the sample has low levels of religiosity. Only about 12 percent report having a belief in God/gods and there is infrequent participation in religious activity across the entire sample. Compared to respondents with two religiously affiliated parents, respondents with only one affiliated parent have lower levels of religiosity across all measures, but compared to respondents with no religiously affiliated parents, they have significantly higher levels of religiosity.

Approximately half of the sample is female and almost 38 percent is urban. The average age is about 41 and about 83 percent of the sample is married. Only 5.5 percent are members of the Chinese Communist Party (CCP). The average education level is less than a high school degree, and the average income level is less than 2,000 Chinese RMB per month.

\section{[Table 2 ABOUT HERE]}

Table 2 presents both the estimated odds ratios from binary logistic regression models predicting whether respondents have a religious affiliation (Model 1) and believe 
in God/gods (Model 2) as well as the estimated odds ratios from ordered logistic regression models predicting increases in respondents' frequency of participation in religious activities (Model 3) and religious salience (Model 4). The results are consistent across each measure of religiosity. Model 1 reveals that individuals with only one religiously affiliated parent have more than 5 times greater odds of being religiously affiliated (Model 1) than individuals with two religiously unaffiliated parents. For respondents with two religiously affiliated parents, this increases to more than 15 times greater odds. Having one religiously affiliated parent is associated with 3.4 times greater odds of believing in God than have no religiously affiliated parents (Model 2). Compared to having no religiously affiliated parents at age 15 , respondents with one religiously affiliated parent have about 3.5 times greater odds of reporting more frequent religious activity (Model 3) and nearly 3 times greater odds of reporting higher levels of religious salience (Model 4).

Higher income levels and being female also significantly increase respondents' likelihood of being religious across these measures. Increased age and being married is associated with greater odds of having a religious affiliation, believing in God/gods, saying religion is important to their lives. CCP members are significantly less likely to be religious than non-members to have a religious affiliation and or say religion is important to them. In fact, the formal rule of the CCP is to prohibit its members to have religious belief and engage in religious practice. However, this survey was conducted at a time when the restrictions were not strictly enforced, so that some CCP members admitted holding religious beliefs or engaging in religious practices. 
[Figure 1 ABOUT HERE]

To aid in interpretation of these results, figures 1 and 2 illustrate the predicted probabilities from the four logistic regression models. Figure 1 shows the predicted probability of having a religious affiliation and believing in God/gods for individuals with no affiliated parents, one affiliated parents, and two affiliated parents. Individuals with one affiliated parent have a significantly higher probability of having a religious affiliation (.44) than individuals with no affiliated parents (.14). Similarly, the predicted probability of believing in God/gods is .24 for individuals with one religious parent and less than .08 for individuals with no religious parents. Figure 2 graphs the predicted probability of participation religious activities and religious salience. On average individuals with no religious parents have a low probability of only occasionally participating in religious activities (.07) and reporting that religion is somewhat important in their lives (.07). Among individuals with one religious parent, these probabilities double to more than .14 and more than .15 percent, respectively.

Overall, the estimates from logistic regression models predicting religiosity in Table 2 confirm the bivariate associations presented in Table 1. The effect of parents' religious heterogamy on all measures of religiosity withstands demographic controls: 
having one religious parent at age 15 is associated with significantly greater religiosity (across all measures) than having no religious parents at age $15 .{ }^{4}$

[Figure 2 ABOUT HERE]

\section{Discussion and Conclusion}

In China, along with economic market transition and globalization in the last four decades, religion has revived and is thriving (Yang 2011). An increasing number of Buddhist and Daoist temples, Islamic mosques, and Christian churches have been reopened or newly constructed, and more and more people are openly practicing religion. Al research has considered the impact of political, economic, and social factors on the growth of religion in Chinese society (Overmyer 2003; Yang 2005; Chau 2010; Yang 2011; Stark and Wang 2015), surprisingly few studies have explored the role of the family context in transmitting religion from one generation to the next. At the present, the majority of Chinese families have two religiously unaffiliated parents. This reality has allowed us to examine and compare having religiously heterogamous parents to having two religiously unaffiliated parents.

Based on prior explanations of the impact of societal characteristics on the salience of religious socialization, we tested two competing hypotheses. Our analyses show that, in the Chinese context, having at least one religious parent is positively associated with an

\footnotetext{
${ }^{4}$ Auxiliary analyses confirm that having two parents who share the same religious affiliation is related to higher levels of religiosity across each dependent variable than having only one religiously affiliated parent.
} 
increased likelihood of being religious across a variety of measures of religiosity, compared with having two unaffiliated parents. More specifically, having only one religiously affiliated parent is related to significantly increased likelihood of having a religious affiliation and believing in God/gods, as well as reporting higher levels of religious salience and frequency of participation in religious activities.

The results are consistent with the findings of Müller et al. (2014) that religious socialization matters more in more secular nations such as China, but run counter to other expectations, specifically that anti-religious policies increase the costs of religious socialization and, therefore, diminish the overall impact of parental religiosity on the religious lives of their children (Müller et al. 2014). China has the highest score of any nation on the Government Restriction Index (GRI) and heavily promotes Marxist Atheism throughout its education system. This analysis indicates that it only takes one religious parent to counteract China's atheist education system, atheist propaganda through mass media, and the party-state's heavy restrictions on religious belief and practice. In the context of China, marriages in which only one partner is religious are quite effective at transmitting religion to children, producing offspring that are significantly more religious than those produced by two nonreligious parents. This is remarkable given the challenges religion faces in Chinese society.

Is this merely a matter of perspective on whether the glass is half empty or half full? Are we merely emphasizing the level of effectiveness - whereas past research has emphasized the level of ineffectiveness - of religiously heterogamous parents' transmission of religion to children. Our study suggests otherwise. In contexts 
experiencing religious decline, researchers have identified religious heterogamy as both indicative of and leading to religious secularization. This, however, is a phenomenon of Western societies rather than a universal trend around the world. In nearly every postCommunist society and the few societies still under Communist rule, religion has been resurging (Greeley 1994; Froese 2001, 2004; Yang 2011). China is one such society, and we find that in China religious heterogamy is sufficiently effective in countering the strongly atheist ideology and antireligious policies.

More importantly, our findings may be indicative of continual growth of religion in China in the coming years. China has been one of the most secular nations in the world over the past half-century, but after surviving radical eradication measures in the 1960s, religion has been reviving since the 1970s. In this context of religious growth, religious heterogamy has become more prevalent than religious homogamy. Although the majority of marriages in China are between partners who are both religiously unaffiliated, an estimated 14 percent of marriages in the sample of the 2007 Spiritual Life Survey of Chinese Residents are between one religiously affiliated and one religiously unaffiliated partner, whereas only 9 percent are between partners who share the same religious affiliation. ${ }^{5}$ Furthermore, interreligious marriages with one religious and one nonreligious spouse are a growing phenomenon: among Chinese born since 1980 there are nearly twice

\footnotetext{
${ }^{5}$ The 2010 China General Social Survey reports a similar trend: About 12 percent of marriages are between one religiously affiliated partner and one unaffiliated partner and about 3 percent of marriages are between partners who share the same religious affiliation.
} 
as many marriages in which one partner has a religious affiliation (15 percent) as there are marriages in which both partners share the same religious affiliation ( 8 percent).

Additionally, respondents born in the 1970s are nearly twice as likely to report having only one religious parent at age 15 (8 percent) than respondents born in the 1930s, 1940s, or 1950s (4 percent). If the pattern found here holds, it is reasonable to expect continual growth of religion in China among the younger generations. With a population of 1.4 billion, religious vitality in China has global significance. The Pew Research Center (2015) projected religious change in the world in the next several decades, assuming that the religious population in China would have little change. But that assumption is misguided based on reports by numerous fieldwork and survey studies of religion in China (Yang 2016).

In considering the implications of these findings, several data limitations warrant mention. First, measuring parental religiosity by religious identity alone does not adequately capture the religious lives of Chinese parents. Maintaining a religious identity in China can have negative political consequences and is therefore a very sensitive matter. Furthermore, Chinese religion tends to emphasize orthopraxis rather than orthodoxy or membership (Ching 1993; Watson 2007), indicating that the SLSC data likely underrepresent the religiosity of respondents' parents. Previous studies of religious socialization (Myers 1996; Smith and Faris 2005; Petts 2015; Denton and Culver 2015) find that the level of parents' religious activity (i.e., service attendance, prayer, scripture reading) matters more than parents' religious identity; however, the best available data only includes the religious affiliation of parents as recalled by the respondent. Future 
analyses should seek to not only use measures of parents' religious behavior, but to use data gathered from the parents themselves. Additionally, these data do not include information on the religion of the respondents' grandparents. Analysis of US data by Bengtson et al. (2009) demonstrates persistent religious influence across three generations in the transmission of religious activity, religious belief, and overall religiousness. Also, Copen and Silverstein found considerable religious similarities across three generations in families, suggesting that grandparents significantly contribute to religious socialization processes (Copen and Silverstein 2007). Compared to the role of grandparents in the lives of American children, grandparents in traditional Chinese culture exercise considerably more influence on the lives of their grandchildren, both directly as co-residents and indirectly through the family hierarchy (F. Bian, Logan, and Bian 1998; Chen, Liu, and Mair 2011; Zeng and Xie 2014). Given the dynamics of Chinese families, it is reasonable to expect similar multi-generational effects on an individual's religiosity.

The impact of parental divorce on the religiosity of young adults has been welldocumented as a moderator of the effective transmission from religion from parents to children (Zhai et al. 2007; Ellison et al. 2011; Uecker and Ellison 2012). These data, however, do not include information on the parents' marital status during the respondents' childhoods. Despite this limitation, only a small proportion of the respondents in the SLSC data would likely have had divorce parents. ${ }^{6}$ The effectiveness of religious socialization

\footnotetext{
${ }^{6}$ Less than 10 percent of the analysis sample were born after 1985, before which the divorce rate in China was extremely low (Qingbin Wang 2001). Beginning in the mid-1980s, divorce in
} 
also varies across religious groups. Parents in some religious groups are more effective at transmitting their religious beliefs, values, and behaviors to their children than parents in other religious groups (Roof and Hoge 1980). Hu and Leamaster (2015) find that in contemporary China religious groups experience cross-generational religious mobility at different rates. Oversampling of religious adherents from all major religious groups in China is needed to reliably estimate variation in the transmission of religion from one generation to the next.

Despite these limitations, the present study contributes to our understanding of the relationship between the religiosity of individuals and the religious affiliations of their parents in several important ways. First, the finding that having one religious parent significantly increases an individual's likelihood of being religious in China indicates that the influence of even one religious parent is strong enough to overcome the competing influences of China's atheist education system and China's strict policies on religion.

China began to slowly increase, but rates only began to surge dramatically in 2002 (Qian Wang and Chang 2010) following changes to China's marriage laws (Davis 2014; Li Mo 2017). Because only 4 percent of my analysis sample was age 15 or younger in 2002 , there are not likely to be many cases of parental divorce represented in these data. 
Given the challenges that religious followers face in the Chinese political environment, the impact of a single parent on the religious life of their child is remarkable. This highlights the significant role of parental religiosity on the religious lives of individuals, particularly in highly secular contexts.

To the extent that the number of children with at least one religious parent increases in Chinese society, and to the extent that religious parents effectively transmit religion to their children, these factors are shaping the future of China's religious landscape by contributing to the growth of religion. Given that religious change in societies primarily occurs across generations (Chaves 1989; Sherkat 2001; Crockett and Voas 2006; Voas and Chaves 2016; Chaves 2017), future research should pay more careful attention to both characteristics of families and societies that impact the effective transmission of religion from one generation to the next. And in the case of religious heterogamy, what has been interpreted as a contributor to religious decline, may in fact be a contributor to religious growth.

\section{Disclosure Statement}

No potential conflict of interest was reported by the authors.

\section{Funding}

This research received no external funding. 


\section{References}

Anders, Sarah F. 1955. "Religious Behavior of Church Families." Marriage and Family Living 17 (1): 54-57.

Bandura, Albert, and Richard H Walters. 1977. "Social Learning Theory."

Bengtson, Vern L., Timothy J. Biblarz, and Robert E.L. Roberts. 2002. How Families Still Matter: A Longitudinal Study of Youth in Two Generations. Cambridge University Press.

Bengtson, Vern L., Casey E. Copen, Norella M. Putney, and Merril Silverstein. 2009. “A Longitudinal Study of the Intergenerational Transmission of Religion.” Edited by Bernhard Nauck and Chin-Chun Yi. International Sociology 24 (3): 325-45.

Berger, Peter L., Grace Davie, and Effie Fokas. Religious America, Secular Europe?: Theme and Variation. Ashgate Publishing, Ltd., 2008.

Bian, Fuqin, John R. Logan, and Yanjie Bian. 1998. “Intergenerational Relations in Urban China: Proximity, Contact, and Help to Parents.” Demography 35 (1): 115-24.

Bruce, Steve. 1999. Choice and Religion: A Critique of Rational Choice Theory. New York: Oxford University Press.

Bruce, Steve. 2011. Secularization: In Defence of an Unfashionable Theory. New York: Oxford University Press.

Call, Vaughn R. A., and Tim B. Heaton. 1997. "Religious Influence on Marital Stability." Journal for the Scientific Study of Religion 36 (3): 382-92.

Chao, L. Luke, and Fenggang Yang. 2018. "Measuring Religiosity in a Religiously Diverse Society: The China Case.” Social Science Research 74 (April): 187-95.

Chau, Adam Yuet. 2010. Religion in Contemporary China: Revitalization and Innovation. New York: Routledge.

Chaves, Mark. 1989. "Secularization and Religious Revival: Evidence from U.S. Church Attendance Rates, 1972-1986.” Journal for the Scientific Study of Religion 28 (4): 464-77. 
Chaves, Mark. 1991. "Family Structure and Protestant Church Attendance: The Sociological Basis of Cohort and Age Effects." Journal for the Scientific Study of Religion 30 (4): 501-14.

Chaves, Mark. 2017. American Religion: Contemporary Trends. Princeton University Press.

Chen, Feinian, Guangya Liu, and Christine A. Mair. 2011. "Intergenerational Ties in Context: Grandparents Caring for Grandchildren in China." Social Forces; a Scientific Medium of Social Study and Interpretation 90 (2): 571-94.

Ching, Julia. 1993. Chinese Religions. Themes in Comparative Religion Series. Palgrave Macmillan Limited.

Clark, Cynthia A, and Everett L Worthington. 1990. Family Variables Affecting the Transmission of Religious Values from Parents to Adolescents: A Review. University Press of America.

Copen, Casey, and Merril Silverstein. 2007. "Transmission of Religious Beliefs Across Generations: Do Grandparents Matter?” Journal of Comparative Family Studies 38 (4): 497-510.

Cornwall, Marie. 1989. "The Determinants of Religious Behavior: A Theoretical Model and Empirical Test." Social Forces 68 (2): 572-92.

Crockett, Alasdair, and David Voas. 2006. "Generations of Decline: Religious Change in 20th-Century Britain." Journal for the Scientific Study of Religion 45 (4): 567-84.

Curtis, Kristen Taylor, and Christopher G Ellison. 2002. "Religious Heterogamy and Marital Conflict: Findings From the National Survey of Families and Households." Journal of Family Issues 23 (4): 551-76.

Davis, Deborah S. 2014. "Demographic Challenges for a Rising China.” Daedalus 143 (2): 26-38.

Denton, Melinda Lundquist, and Julian Culver. 2015. "Family Disruption and Racial Variation in Adolescent and Emerging Adult Religiosity." Sociology of Religion; Washington 76 (2): 222-39. 
Ellison, Christopher G., Anthony B. Walker, Norval D. Glenn, and Elizabeth Marquardt. 2011. "The Effects of Parental Marital Discord and Divorce on the Religious and Spiritual Lives of Young Adults.” Social Science Research 40 (2): 538-51.

Erickson, Joseph A. 1992. “Adolescent Religious Development and Commitment: A Structural Equation Model of the Role of Family, Peer Group, and Educational Influences.” Journal for the Scientific Study of Religion 31 (2): 131-52.

Froese, Paul. 2001. "Hungary for Religion: A Supply-Side Interpretation of the Hungarian Religious Revival.” Journal for the Scientific Study of Religion 40 (2): 251-268.

Froese, Paul. 2004. "After Atheism: An Analysis of Religious Monopolies in the PostCommunist World.” Sociology of Religion, Volume 65, Issue 1, 1 March 2004, Pages 57-75.

Greeley, Andrew. 1994. “A Religious Revival in Russia?” Journal for the Scientific Study of Religion, 33(3), 253-272.

Gunnoe, Marjorie Lindner, and Kristin A. Moore. 2002. "Predictors of Religiosity Among Youth Aged 17-22: A Longitudinal Study of the National Survey of Children.” Journal for the Scientific Study of Religion 41 (4): 613-22.

Havens, Joseph. 1964. “A Study of Religious Conflict in College Students.” The Journal of Social Psychology 64 (1): 77-87.

Himmelfarb, Harold S. 1975. "Measuring Religious Involvement.” Social Forces 53 (4): 606-18.

Himmelfarb, Harold S. 1979. "Agents of Religious Socialization Among American Jews.” The Sociological Quarterly 20 (4): 477-94.

Himmelfarb, Harold S. 1980. "The Study of American Jewish Identification: How It Is Defined, Measured, Obtained, Sustained and Lost." Journal for the Scientific Study of Religion 19 (1): 48-60.

Hoge, Dean R. 1994. Vanishing Boundaries : The Religion of Mainline Protestant Baby Boomers. Edited by Benton Johnson and Donald A Luidens. Louisville, Ky.: Louisville, Ky. : Westminster/John Knox Press. 
Hoge, Dean R., and Gregory H. Petrillo. 1978. "Determinants of Church Participation and Attitudes Among High School Youth.” Journal for the Scientific Study of Religion 17 (4): 359-79.

$\mathrm{Hu}$, Anning, and Reid J. Leamaster. 2015. "Intergenerational Religious Mobility in Contemporary China." Journal for the Scientific Study of Religion 54 (1): 79-99.

Hunsberger, Bruce, and Laurence B Brown. 1984. "Religious Socialization, Apostasy, and the Impact of Family Background." Journal for the Scientific Study of Religion, 239-51.

Kalmijn, Matthijs. 1991. "Shifting Boundaries: Trends in Religious and Educational Homogamy." American Sociological Review 56 (6): 786-800.

Kelley, Jonathan, and Nan Dirk De Graaf. 1997. "National Context, Parental Socialization, and Religious Belief: Results from 15 Nations." American Sociological Review 62 (4): 639-59.

King, Morton B., and Richard A. Hunt. 1972. "Measuring the Religious Variable:

Replication." Journal for the Scientific Study of Religion 11 (3): 240-51.

Lawton, Leora E., and Regina Bures. 2001. "Parental Divorce and the 'Switching' of Religious Identity.” Journal for the Scientific Study of Religion 40 (1): 99-111.

Levin, Jeffrey S., Robert Joseph Taylor, and Linda M. Chatters. 1995. “A

Multidimensional Measure of Religious Involvement for African Americans." The Sociological Quarterly 36 (1): 157-73.

Long, J Scott, and Jeremy Freese. 2006. Regression Models for Categorical Dependent Variables Using Stata. Stata press.

Martin, Todd F., James M. White, and Daniel Perlman. 2003. "Religious Socialization: A Test of the Channeling Hypothesis of Parental Influence on Adolescent Faith Maturity." Journal of Adolescent Research 18 (2): 169-87.

Mayrl, Damon, and Freeden Oeur. 2009. "Religion and Higher Education: Current Knowledge and Directions for Future Research." Journal for the Scientific Study of Religion 48 (2): 260-75. 
MEPRC (Ministry of Education of the People's Republic of China). 2001. "Revised Course Standards of the Elementary School Course of Ideological and Moral Education and Middle School Course of Ideological and Political Education," Ministry of Education circular, www.moe.edu.cn/publicfiles/business/htmlfiles/moe/moe_711/200408/618.html.

Mo, Li. 2017. "Trends in the Divorce Rate and Its Regional Disparity in China." Journal of Comparative Family Studies 48 (4): 383-94.

Müller, Tim S, Nan Dirk De Graaf, and Peter Schmidt. 2014. "Which Societies Provide a Strong Religious Socialization Context? Explanations Beyond the Effects of National Religiosity." Journal for the Scientific Study of Religion 53 (4): 739-59.

Myers, Scott M. 1996. "An Interactive Model of Religiosity Inheritance: The Importance of Family Context." American Sociological Review 61 (5): 858-66.

Nelsen, Hart M. 1980. "Religious Transmission Versus Religious Formation: Preadolescent-Parent Interaction.” The Sociological Quarterly 21 (2): 207-18. Nelsen, Hart M. 1990. "The Religious Identification of Children of Interfaith Marriages." Review of Religious Research 32 (2): 122-34.

Norris, Pippa, and Ronald Inglehart. 2011. Sacred and Secular: Religion and Politics Worldwide. Cambridge University Press.

Overmyer, Daniel L. 2003. "Religion in China Today: Introduction." The China Quarterly 174 (June): 307-16.

Park, Jerry Z., and Elaine Howard Ecklund. 2007. "Negotiating Continuity: Family and Religious Socialization for Second-Generation Asian Americans." The Sociological Quarterly 48 (1): 93-118.

Pearce, Lisa D., George M. Hayward, and Jessica A. Pearlman. 2017. "Measuring Five Dimensions of Religiosity Across Adolescence." Review of Religious Research 59 (3): 367-93.

Pearce, Lisa, and Melinda Lundquist Denton. 2011. A Faith of Their Own: Stability and Change in the Religiosity of America's Adolescents. Oxford University Press. 
Petersen, Larry R. 1986. "Interfaith Marriage and Religious Commitment Among Catholics." Journal of Marriage and Family 48 (4): 725-35.

Petts, Richard J. 2015. "Parental Religiosity and Youth Religiosity: Variations by Family Structure.” Sociology of Religion 76 (1): 95-120.

Petts, Richard J., and Chris Knoester. 2007. 'Parents' Religious Heterogamy and Children's Well-Being.” Journal for the Scientific Study of Religion 46 (3): 37389.

Pew Research Center. 2015. "The Future of World Religions: Population Growth Projections, 2010-2050.” Washington, D.C.

Pew Research Center. 2016. "One-in-Five U.S. Adults Were Raised in Interfaith Homes." Washington, D.C.

Pew Research Center. 2018. "Global Uptick in Government Restrictions on Religion in 2016." Washington, D.C.

Putney, Snell, and Russell Middleton. 1961. "Rebellion, Conformity, and Parental Religious Ideologies.” Sociometry 24 (2): 125-35.

Regnerus, Mark D., Christian Smith, and Brad Smith. 2004. "Social Context in the Development of Adolescent Religiosity." Applied Developmental Science 8 (1): $27-38$.

Renminwang. 2006. "University Ideological and Political Courses Will Be Regrouped from Eight Courses to Four Courses," by China News Service, July 4, 2006, http://edu.people.com.cn/GB/4558733.html.

Roof, Wade Clark. 1999. Spiritual Marketplace: Baby Boomers and the Remaking of American Religion. Princeton University Press.

Roof, Wade Clark, and Dean R. Hoge. 1980. "Church Involvement in America: Social Factors Affecting Membership and Participation." Review of Religious Research 21 (4), 405-26.

Rosenfeld, Michael J. 2008. "Racial, Educational and Religious Endogamy in the United States: A Comparative Historical Perspective.” Social Forces 87 (1): 1-31. 
Schwadel, Philip, John D. McCarthy, and Hart M. Nelsen. 2009. “The Continuing Relevance of Family Income for Religious Participation: U.S. White Catholic Church Attendance in the Late 20th Century." Social Forces 87 (4): 1997-2030. Sherkat, Darren E. 1998. "Counterculture or Continuity? Competing Influences on Baby Boomers' Religious Orientations and Participation.” Social Forces 76 (3), $1087-$ 1114.

Sherkat, Darren E. 2001. "Tracking the Restructuring of American Religion: Religious Affiliation and Patterns of Religious Mobility, 1973-1998." Social Forces 79 (4): 1459-93.

Smith, Christian, and Melina Lundquist Denton. 2009. Soul Searching: The Religious and Spiritual Lives of American Teenagers. Oxford University Press.

Smith, Christian, and Robert Faris. 2005. "Socioeconomic Inequality in the American Religious System: An Update and Assessment." Journal for the Scientific Study of Religion 44 (1): 95-104.

SMRT (State Ministry of Radio and Television). 2003. "Opinions about Atheist Propaganda and Scientific Education Propaganda through Radio and Television," China.com.cn, 2003, www.china.com.cn/chinese/PI-c/425211.htm.

Solt, Frederick, Philip Habel, and J. Tobin Grant. 2011. "Economic Inequality, Relative Power, and Religiosity." Social Science Quarterly 92 (2): 447-65.

Stark, Rodney, and Roger Finke. 2000. Acts of Faith: Explaining the Human Side of Religion. University of California Press.

Stark, Rodney, and Xiuhua Wang. 2015. A Star in the East: The Rise of Christianity in China. Templeton Press.

Stolzenberg, Ross M., Mary Blair-Loy, and Linda J. Waite. 1995. "Religious Participation in Early Adulthood: Age and Family Life Cycle Effects on Church Membership." American Sociological Review 60 (1): 84-103.

Sullins, D. Paul. 2006. "Gender and Religion: Deconstructing Universality, Constructing Complexity." American Journal of Sociology 112 (3): 838-80. 
Uecker, Jeremy E., and Christopher G. Ellison. 2012. "Parental Divorce, Parental Religious Characteristics, and Religious Outcomes in Adulthood." Journal for the Scientific Study of Religion 51 (4): 777-94.

Voas, David. 2003. "Intermarriage and the Demography of Secularization." The British Journal of Sociology 54 (1): 83-108.

Voas, David, and Mark Chaves. 2016. "Is the United States a Counterexample to the Secularization Thesis?" American Journal of Sociology 121 (5): 1517-56.

Voas, David, and Ingrid Storm. "The Intergenerational Transmission of Churchgoing in England and Australia." Review of Religious Research 53, no. 4 (2012): 377-395. Wang, Qian, and Lei Chang. 2010. "Parenting and Child Socialization in Contemporary China." Edited by Edited by Michael Harris Bond. Oxford Handbook of Chinese Psychology, February.

Wang, Qingbin. 2001. "China's Divorce Trends in the Transition Toward a Market Economy." Journal of Divorce \& Remarriage 35 (1-2): 173-89.

Warner, R. Stephen. "Work in Progress Toward a New Paradigm for the Sociological Study of Religion in the United States." American Journal of Sociology 98, no. 5 (1993): 1044-1093.

Watson, James L. 2007. “Orthopraxy Revisited.” Modern China 33 (1): 154-58.

Williams, Lee M., and Michael G. Lawler. 2002. "Religious Heterogamy and Religiosity: A Comparison of Interchurch and Same-Church Individuals." Journal for the Scientific Study of Religion 40 (3): 465-78.

Willits, Fern K., and Donald M. Crider. 1989. "Church Attendance and Traditional Religious Beliefs in Adolescence and Young Adulthood: A Panel Study.” Review of Religious Research 31 (1): 68-81.

Wilson, John, and Darren E. Sherkat. 1994. "Returning to the Fold." Journal for the Scientific Study of Religion 33 (2): 148-61.

Wright, David M., Michael Rosato, and Dermot O'Reilly. 2017. “Influence of Heterogamy by Religion on Risk of Marital Dissolution: A Cohort Study of 20,000 Couples." European Journal of Population 33 (1): 87-107. 
Xie, Ying, Yunping Tong, and Fenggang Yang. 2017. "Does Ideological Education in China Suppress Trust in Religion and Foster Trust in Government?" Religions; Basel 8 (5): 94.

Xie, Yu, and Xiang Zhou. 2014. "Income Inequality in Today's China." Proceedings of the National Academy of Sciences of the United States of America 111 (19): 6928-33.

Yang, Fenggang. 2005. "Lost in the Market, Saved at McDonald's: Conversion to Christianity in Urban China." Journal for the Scientific Study of Religion 44 (4): $423-41$.

Yang, Fenggang. 2011. Religion in China: Survival and Revival Under Communist Rule. Oxford University Press.

Yang, Fenggang. 2016. "Exceptionalism or Chinamerica?: Measuring Religious Change in the Globalizing World Today." Journal of the Scientific Study of Religion 55(1):722.

Yang, Fenggang. 2018. "Evangelization amid Cooperation, Accommodation, and Resistance.” In D. Philpott \& T. Shah (Eds.), Under Caesar's Sword: How Christians Respond to Persecution (Law and Christianity, pp. 334-357).

Cambridge: Cambridge University Press. doi:10.1017/9781108348331.011.

Zeng, Zhen, and Yu Xie. 2014. "The Effects of Grandparents on Children's Schooling: Evidence From Rural China.” Demography 51 (2): 599-617.

Zhai, Jiexia Elisa, Christopher G. Ellison, Norval D. Glenn, and Elizabeth Marquardt. 2007. "Parental Divorce and Religious Involvement Among Young Adults." Sociology of Religion 68 (2): 125-44.

Zhongxuanfa 中宣发. 2004. “On Further Strengthening the Work of Research and Propagative Education of Marxist Atheism," circular No. 13 of 2004, was found on vomcanada.com, 2004, www.vomcanada.com/download/china_secretdoc_ch.pdf. 
Table 1. Descriptive Statistics for All Variables (Weighted \%)

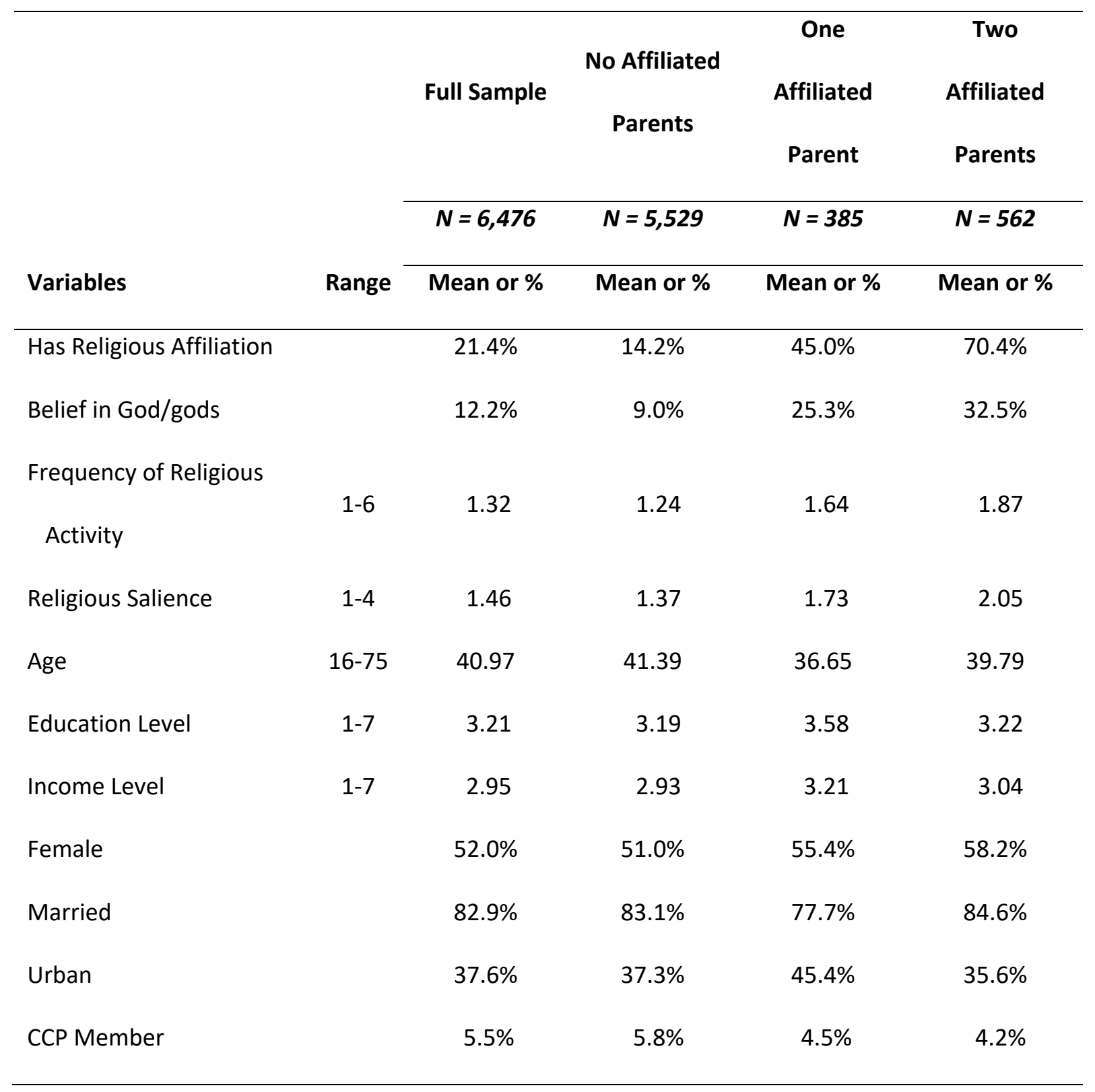


Table 2. Odds Ratios from Logistic Regression Models Predicting Religious Affiliation, Belief in God/gods, Frequency of Religious Activity, and Religious Salience

\begin{tabular}{|c|c|c|c|c|}
\hline & Model 1 & Model 2 & Model 3 & Model 4 \\
\hline & $\begin{array}{l}\text { Has Religious } \\
\text { Affiliation }^{\mathrm{a}}\end{array}$ & $\begin{array}{c}\text { Belief in } \\
\text { God/gods }\end{array}$ & $\begin{array}{l}\text { Freq. of } \\
\text { Religious } \\
\text { Activityb }^{b}\end{array}$ & $\begin{array}{l}\text { Religious } \\
\text { Salience }^{b}\end{array}$ \\
\hline One Affiliated & $5.311^{* * *}$ & $3.397^{* * *}$ & $3.483^{* * *}$ & $2.813^{* * *}$ \\
\hline Parent & $(0.898)$ & $(0.654)$ & $(0.545)$ & $(0.382)$ \\
\hline Two Affiliated & $15.264^{* * *}$ & $4.931^{* * *}$ & $5.618^{* * *}$ & $5.192^{* * *}$ \\
\hline Parents & $(2.282)$ & $(0.711)$ & (0.698) & $(0.625)$ \\
\hline CCP Member & $0.572^{*}$ & $0.422^{* *}$ & 0.711 & 0.902 \\
\hline & (0.139) & $(0.114)$ & $(0.141)$ & $(0.132)$ \\
\hline Age & $1.016^{* * *}$ & $1.011^{*}$ & 1.006 & $1.016^{* * *}$ \\
\hline & $(0.005)$ & $(0.005)$ & $(0.004)$ & $(0.004)$ \\
\hline
\end{tabular}




\begin{tabular}{lllll} 
Female & $1.566^{* * *}$ & $1.753^{* * *}$ & $1.569^{* * *}$ & $1.303^{* * *}$ \\
& $(0.165)$ & $(0.207)$ & $(0.151)$ & $(0.104)$ \\
Education Level & 0.906 & 0.973 & 0.978 & 1.010 \\
& $(0.052)$ & $(0.060)$ & $(0.048)$ & $(0.044)$ \\
Married & $0.617^{* *}$ & $0.731^{*}$ & 0.879 & $0.651^{* * *}$ \\
& $(0.092)$ & $(0.116)$ & $(0.119)$ & $(0.073)$ \\
Urban & 1.062 & $1.484^{* *}$ & $1.270^{*}$ & $1.343^{* * *}$ \\
& $(0.120)$ & $(0.189)$ & $(0.141)$ & $(0.117)$ \\
Income Level & $1.092^{*}$ & 1.072 & $1.128^{* *}$ & $1.117^{* * *}$ \\
& $(0.046)$ & $(0.047)$ & $(0.043)$ & $(0.035)$ \\
\hline Observations & 6,476 & 6,476 & 6,476 & 6,476
\end{tabular}

Exponentiated coefficients; Standard errors in parentheses

${ }^{*} p<0.05,{ }^{* *} p<0.01,{ }^{* * *} p<0.001$

${ }^{a}$ Binary logistic regression ${ }^{b}$ Ordered logistic regression 

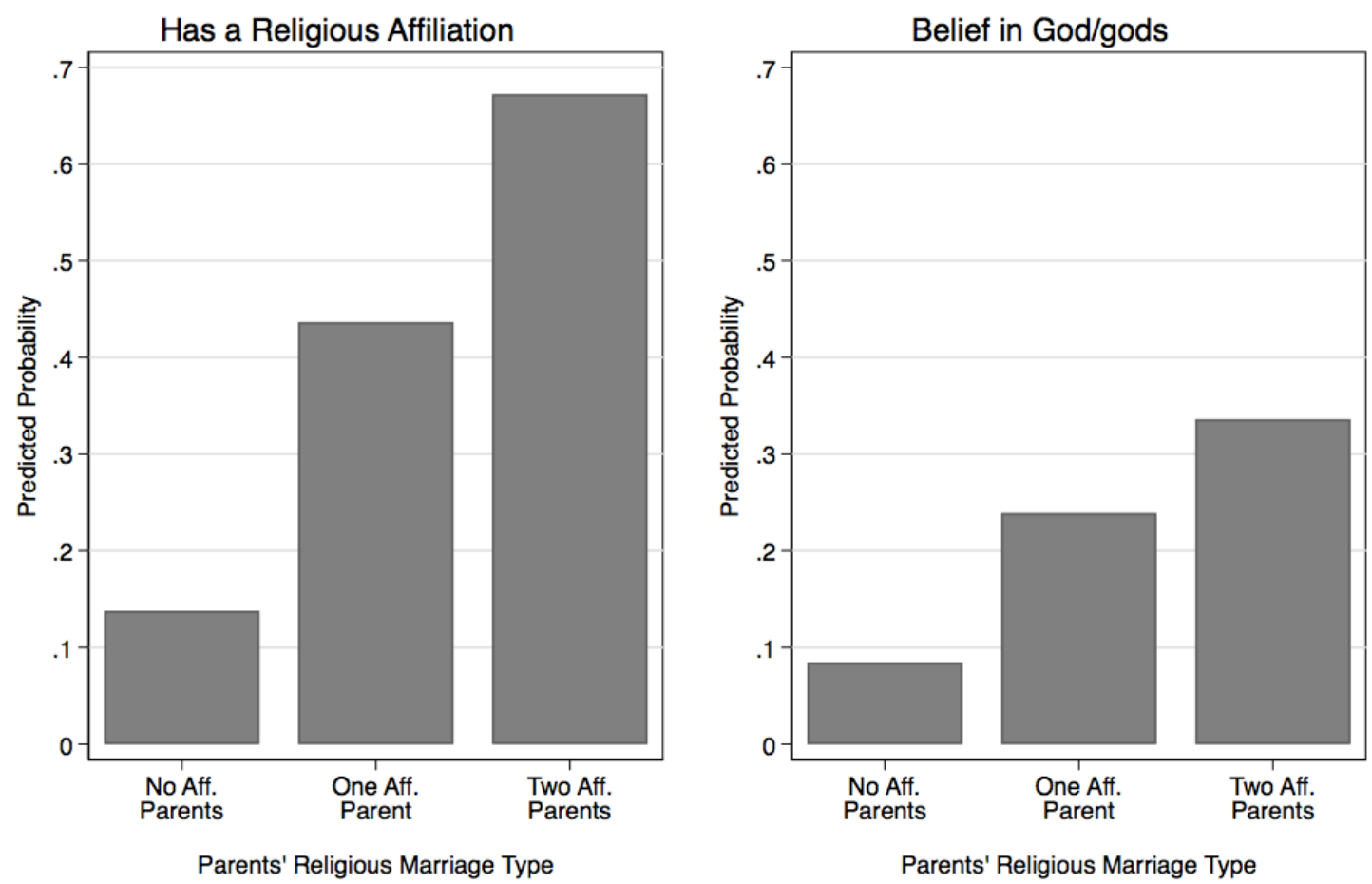

Figure 1. Predicted probabilities of having a religious affiliation and belief in God/gods by parents' religious marriage type

Note: Predictions use estimates from binary logistic regression models 1 and 2 in Table 2 and are calculated with all other covariates held at their actual values. 

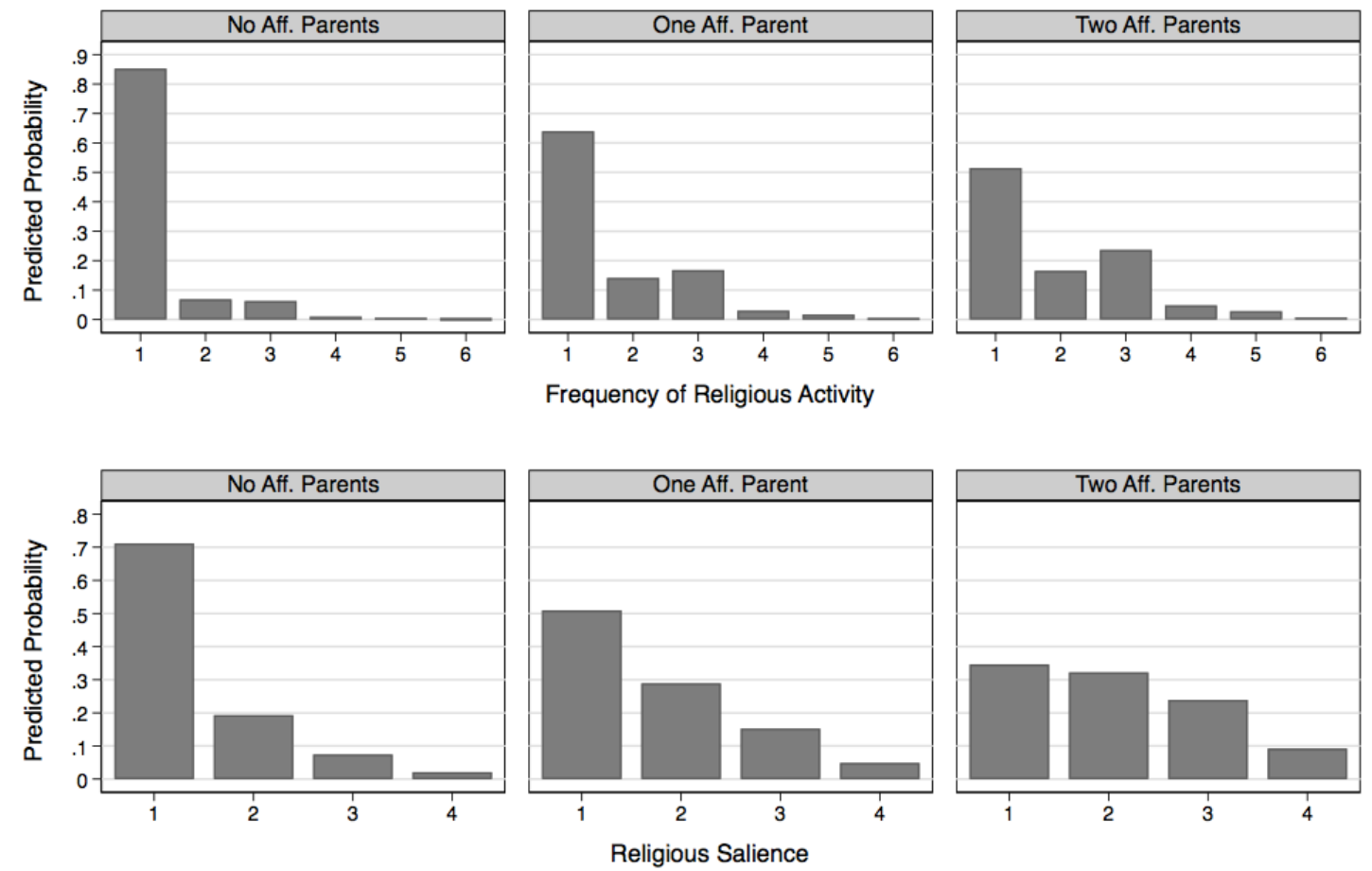

Figure 2. Predicted probabilities of frequency of religious activity and religious salience by parents' religious marriage type

Note: Predictions use estimates from ordered logistic regression models 3 and 4 in Table 2 and are calculated with all other covariates held at their actual values. 